\title{
Characterization of Oomycete Species Associated With Root and Crown Rot of English Walnut in Chile
}

\author{
Jeannette Guajardo, ${ }^{1}$ Sebastián Saa, ${ }^{1}$ Natalia Riquelme, ${ }^{1}$ Gregory Browne, ${ }^{2}$ Cristian Youlton, ${ }^{1}$ Mónica Castro, ${ }^{1}$ \\ and Ximena Besoain ${ }^{1, \dagger}$ \\ ${ }^{1}$ Escuela de Agronomía, Facultad de Ciencias Agronómicas y de los Alimentos, Pontificia Universidad Católica de Valparaíso, \\ Casilla 4D, Quillota, Chile; and ${ }^{2}$ USDA-ARS, Crops Pathology and Genetics Research Unit, Department of Plant Pathology, \\ University of California, Davis, CA 95616, U.S.A.
}

\begin{abstract}
English (Persian) walnut (Juglans regia) trees affected by root and crown rot were surveyed in five regions of central Chile between 2015 and 2017. In each region, nine orchards, ranging from 1 to 21 years old, were randomly selected and inspected for incidence and severity of tree decline associated with crown and root rot. Soil and symptomatic crown and root tissues were collected and cultured in $\mathrm{P}_{5} \mathrm{ARP}$ semiselective medium to isolate potential oomycete pathogens, which were identified through morphology and molecularly using ITS sequences in the rDNA

gene and beta tubulin gene. The most frequently isolated species was Phytophthora cinnamomi. Pathogenicity tests were conducted with representative oomycete isolates. P. cinnamomi, P. citrophthora, and Pythium ultimum were all pathogenic in J. regia. Nevertheless, only $P$. cinnamomi and $P$. citrophthora were pathogenic to English walnut. $P y$. ultimum caused limited levels of root damage to English walnut seedlings. Our research indicates that as the Chilean walnut industry has expanded, so have walnut crown and root rots induced by oomycetes.
\end{abstract}

In the last 10 years, English walnut (Juglans regia L.) production area in Chile has expanded from 10,000 ha (2007) to 33,000 ha (2016), with 75,947 tons of walnuts produced in 2015 (ODEPA 2016). Chile is now the third-ranked exporter of walnuts worldwide. Chilean walnut production extends from the Atacama region in the north (latitude -27.36) to the Los Rios region in the south (latitude -39.80) and encompasses a wide range of climatic and edaphic conditions. English walnut orchards in all of these regions have reported trees with chlorosis, defoliation, shoot dieback, and root rot, often in association with crown rot. However, no recent surveys of this decline or its associated pathogens are available. Most commercial English walnut cultivars in Chile are grafted on English walnut rootstocks, which are considered to be highly susceptible to Phytophthora species (Mircetich and Matheron 1983).

In California, more than 10 species of Phytophthora have been associated with crown and root rots of walnut trees, with P. cinnamomi and $P$. citricola being the most aggressive and difficult Phytophthora species to control (Browne et al. 2011; Mircetich and Matheron 1983). In Europe, Belisario et al. (2001) reported that the main species affecting walnut is $P$. cinnamomi, but $P$. cactorum, $P$. cambivora, $P$. chlamydospora, $P$. cryptogea, $P$. citricola, $P$. gonapodyides, $P$. megasperma, and $P$. nicotianae were also involved (Belisario et al. 1997, 2001, 2003, 2006, 2012, 2016; Dervis 2016; Erwin and Ribeiro 1996; Kovacs et al. 2013; Kurbetli 2013; Vettraino et al. 2002, 2003). The first report of a Phytophthora species in English walnut orchards in Chile was made by English et al. (1967), who isolated $P$. cactorum from soil around declining English walnut trees in the Valparaíso region. At that time, English walnut orchards were

${ }^{\dagger}$ Corresponding author: X. Besoain; E-mail: ximena.besoain@pucv.cl

Funding: This work was supported by the Ministerio de Agricultura, Fundación para la Innovación Agraria (FIA) and the Asociación de Productores y Exportadores de Nueces de Chile (ChileNut), project number (PYT2016-0065).

*The $\boldsymbol{e}$-Xtra logo stands for "electronic extra" and indicates that one supplementary figure and two supplementary tables are published online.

Accepted for publication 24 September 2018.

(C) 2019 The American Phytopathological Society concentrated in the Metropolitana and O'Higgins regions, although there were no reports of walnut root and crown rot there. A few years later, Phytophthora species associated with root and crown rot of English walnut were reported in the Valparaiso region, including $P$. cactorum (INIA 1969), P. cinnamomi, and P. citrophthora (Rojic and Cancino 1975). Since the 1970s, the Chilean English walnut industry has been expanding, with a strong increase in the last 10 years. In a 2015-2016 survey conducted in central Chile, P. cinnamomi was found in 20 of the 49 English walnut orchards (Guajardo et al. 2017). This pathogen has also been isolated from grapes (Vitis vinifera) (Latorre et al. 1997), avocado (Persea americana) (Besoain et al. 2005), and blueberry (Vaccinium corymbosum) (Larach et al. 2009) in central Chile.

Pythium (Py.) and Phytopythium (Phy.) species have been reported to cause root rot in many perennial crop plants, including apple (Utkhede and Smith 1991), grape (Spies et al. 2011), and pistachio (Fichtner et al. 2016).

It may be possible to reduce losses due to root and crown rot diseases among Chilean English walnut orchards by implementing integrated pest management approaches that include the use of resistant rootstocks, cultural management practices, and the use of systemic fungicides (Browne et al. 2011, 2015; Mircetich et al. 1998). However, implementation of such approaches would be greatly facilitated by knowledge of the pathogens, their geographical distributions, and their biology in the regions of concern. For example, rootstocks of J. regia are more susceptible than Paradox hybrid rootstock (J. regia $\times$ $J$. hindsii) to several species of Phytophthora (Matheron and Mircetich 1985; Mircetich et al. 1998) that attack walnut in California, but it is unknown whether root and crown rot pathogens in Chile are similar to those obtained in California, so we cannot conclude that they have an equal level of susceptibility. Therefore, this study was conducted to: (i) evaluate the incidence and severity of root and crown rot disease in English walnut trees in central Chile, (ii) isolate and identify oomycetes that cause root and crown rot of English walnut in Chile, and (iii) study the pathogenicity of oomycetes commonly associated with root and crown rot in English walnut.

\section{Materials and Methods}

Field survey. In the spring (October to December) of 2015, an extensive diagnostic survey was conducted in 45 English walnut orchards distributed among the five main English walnut producing regions of Chile: Coquimbo, Valparaíso, Metropolitana, O'Higgins, 
and Maule. In each region, nine randomly selected English walnut orchards, ranging from 1 to 21 years old, were surveyed (Fig. 1). All English walnut trees were grafted on J. regia rootstock. The proportion of orchards with at least one tree affected by root and crown rot was estimated. To determine the incidence and severity of this disease, quadrants of 100 trees were randomly selected and inspected for root and crown rot disease symptoms: leaf chlorosis, leaf fall, and crown canker. Incidence was estimated as the percentage of diseased trees over the total number of trees evaluated $(n=100)$. Disease severity was determined using a scale of 0 to 4 , where: $0=$ a healthy tree, $1=$ a tree with green leaves, but with irregular sprouting, $2=$ a tree with irregular sprouting and defoliated zones, $3=$ a tree with chlorosis, irregular bud breaking, and defoliated zones, and $4=\mathrm{a}$ defoliated and dead tree. The severity of disease in each orchard was expressed using the canopy damage index $\left({ }_{C} \mathrm{DI}\right)$ (McKinney $1923)$, according to the following equation: ${ }_{C} \mathrm{DI}(\%)=\left(\sum(\mathrm{nv})\right.$ $\left.(\mathrm{NV})^{-1} 100\right)$, where $\mathrm{n}=$ number of trees per disease rating scale; $\mathrm{v}=$ disease rating scale; $\mathrm{N}=$ total number of trees observed; $\mathrm{V}=$ maximum range of the attack scale.

Sampling and isolation. From October 2015 to April 2017, rotten root samples and occasionally tissue samples taken from the margins of trunk cankers were collected from the 45 orchards previously surveyed. For additional comparisons, samples were taken from 10 orchards in southern Chile (Bío Bío Region). Soil samples were taken 5 to $30 \mathrm{~cm}$ deep where the main feeder roots were located. A total of 140 samples were taken to the laboratory and used for isolations (Guajardo et al. 2017). Necrotic tissue samples (3 to $4 \mathrm{~mm}$ long), obtained from the margin of the lesions of root rot cankers, were washed three times with sterile distilled water (SDW) and plated

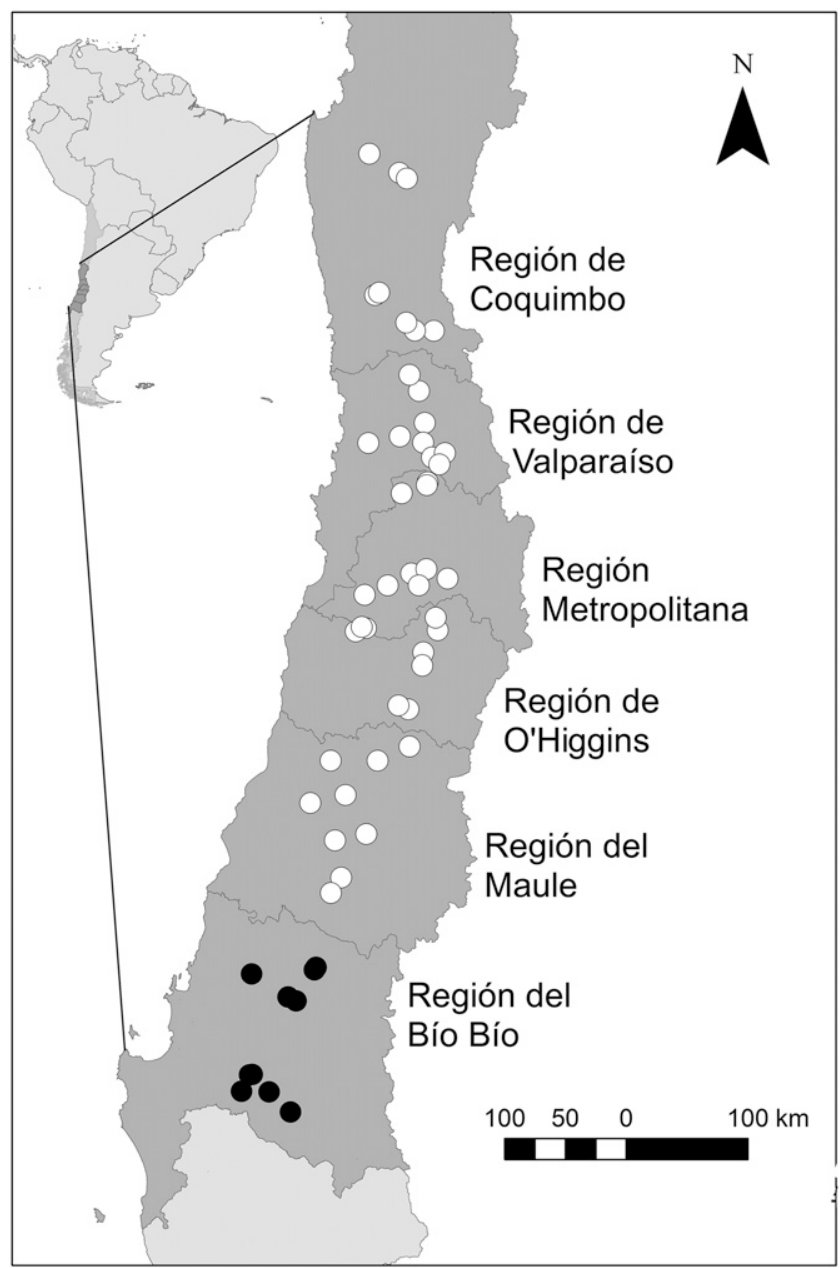

Fig. 1. English walnut orchards in Chile covered in diagnostic surveys for root rot disease, carried out in the spring of 2015. on $\mathrm{P}_{5} \mathrm{ARP}$ semiselective medium (5 $\mathrm{mg}$ pimaricin, $250 \mathrm{mg}$ ampicillin, $10 \mathrm{mg}$ rifampicin, $100 \mathrm{mg}$ pentachloronitrobenzene, and $17 \mathrm{~g}$ cornmeal agar in 1,000 ml distilled water) and potato-dextrose agar (PDA; Merck, Darmstadt, Germany) acidified with $1 \mathrm{ml}$ of lactic acid (APDA) for cankered tissue isolation (Jeffers and Martin 1986). Plates were incubated in the dark for 7 days at $25^{\circ} \mathrm{C}$. Soil samples $(300 \mathrm{~g})$ were placed in a $500-\mathrm{ml}$ pot and saturated with SDW before placing on Rhododendron leaves as bait (Themann and Werres 1998). After 96-120 h, the leaves exhibiting necrotic lesions were cut (5 mm pieces) and cultured in $\mathrm{P}_{5} \mathrm{ARP}$ medium. Hyphal tips were subcultured from the margins of colonies developed on $\mathrm{P}_{5} \mathrm{ARP}$ and transferred to fresh APDA and cornmeal agar (CMA; Merck, Darmstadt, Germany).

Morphological and molecular identification. Phytophthora isolates were identified by comparing morphological characteristics of the colonies, sporangia, chlamydospores, and hyphal swellings, with descriptions reported in the literature (Erwin and Ribeiro 1996; Stamps et al. 1990). For Pythium species we used the descriptions of Waterhouse (1968) and De Cock et al. (2015). Phytophthora-like isolates were identified molecularly by the use of the ITS region and confirmed by beta-tubulin gene. Analysis of sexual structures was not included. Colony morphology was determined on 5-day-old cultures growing on APDA and CMA at $25^{\circ} \mathrm{C}$ in the dark. Sporangium production was induced by placing mycelial discs ( $3 \mathrm{~mm}$ diameter) in carrot juice ( $500 \mathrm{~g}$ carrot boiled for $15 \mathrm{~min}$ in 1 liter SDW) on glass plates under continuous light for $48 \mathrm{~h}$ at $24^{\circ} \mathrm{C}$ (Larach et al. 2009). Colonies growing from the mycelial discs were washed with SDW and treated for $3 \mathrm{~min}$ at $5^{\circ} \mathrm{C}$ soaking in saline solution $(2.36 \mathrm{~g}$ $\mathrm{CaNO}_{3}, 0.5 \mathrm{~g} \mathrm{KNO}_{3}, 1 \mathrm{~g} \mathrm{MgSO}_{4}$, and $1 \mathrm{ml}$ chelated iron solution [13 $\mathrm{g} \cdot$ liter $^{-1}$ ethylene diamine tetra acetic iron, $7.5 \mathrm{~g} \cdot$ liter $^{-1} \mathrm{KOH}$, and $24.5 \mathrm{~g} \cdot$ liter $^{-1} \mathrm{FeSO}_{4}$ ] in 1 liter of SDW) (Erwin and Ribeiro 1996). Subsequently, the mycelium was rinsed with SDW and incubated in $1 \% \mathrm{wt} / \mathrm{vol}$ soil extract for $48 \mathrm{~h}$ at $24^{\circ} \mathrm{C}$ under light. Sporangia, chlamydospores, and hyphal swellings were then examined under a light microscope. In total, 30 samples of each structure were examined per isolate (Nikon, eclipse Ni-U).

At least one isolate tentatively identified as Phytophthora in each English walnut production region was confirmed by molecular analyses. DNA was extracted from fresh mycelium developed in pure cultures on PDA medium for $48-72 \mathrm{~h}$ at $25^{\circ} \mathrm{C}$ using the DNeasy Plant Mini Kit (QIAGEN). The ITS1-5.8S-ITS2 region of the ribosomal DNA was amplified using the primers ITS4 $5^{\prime}$ TCCTCCGCTTATTGATATGC- ${ }^{\prime}$ ' and ITS5 5'-GGAAGTAAAAG TCGTAACAAGG-3' (White et al. 1990). The beta tubulin gene was amplified using the primers BT2aF 5'-GGTAACCAAATCGGT GCTGCTTTC-3' and BT2bR 5'-ACCCTCAGTGTAGTGACCCTT GGC-3' (Glass and Donaldson 1995). Amplification reactions were prepared in the final volume of $22 \mu \mathrm{l}$. All the employed methodology was done according to Sapphire Amp Fast PCR Master Mix (Takara, Japan). For each reaction, $1 \mu l$ of DNA was used. All reactions were performed using a thermal cycler (Bioer, China) under the following conditions: $94^{\circ} \mathrm{C}, 1 \mathrm{~min}$ initial denaturation, followed by 35 cycles that included denaturation at $98^{\circ} \mathrm{C}$ for $5 \mathrm{~s}$, annealing at $55^{\circ} \mathrm{C}$ for $5 \mathrm{~s}$, extension at $72^{\circ} \mathrm{C}$ for $5 \mathrm{~s}$, and a final elongation at $72^{\circ} \mathrm{C}$ for $1 \mathrm{~min}$. The PCR products were visualized by electrophoresis in $1 \%$ agarose in TAE buffer (Winkler, Chile) stained with gel red (Biotium, USA) and visualized on a UV transilluminator (Vilber Lourmat, France). Amplified products were purified and sequence in both directions by Macrogene (South Korea). Analyses of the sequence data were conducted using the Geneious 10.0.6 software and aligned using BLASTN (NCBI/BLAST), considering the searches in GenBank that showed 99 to $100 \%$ similarity with reference sequences, including ex-types. Sequences were deposited in GenBank (Table 1).

Pathogenicity test. Pure cultures of oomycete species were used for pathogenicity tests. The tested isolates included three isolates of P. cinnamomi (PN 1858, PN 1955, and PN 1956), two isolates of P. citrophthora (PN 1994 and PN 1995), two isolates of P. humicola (PN 1875 and PN 1943), three isolates of Phy. vexans (PN 1866, PN 1872, and PN 1909), and one isolate of Py. ultimum 
(PN 1665). Considering that Phy. litorale and Phy. mercuriale were only occasionally isolated, no pathogenicity tests were performed with isolates of these species. Three-month-old ungrafted plants of $J$. regia, grown in 3-liter pots with 1:1 peat:sterile sand substrate, were used for inoculation. The plants were watered every 2 days and fertilized with $9 \mathrm{~g}$ Ultrasol Multipurpose (SQM, Santiago, Chile) per plant, applied once at preplanting. Four plants for each isolate were used, and four plants remained noninoculated as controls. Plants were inoculated with zoospores obtained from a suspension of sporangia (mycelia was filtered with a sterile gauze) incubated for $20 \mathrm{~min}$ at $4{ }^{\circ} \mathrm{C}$ and then $1 \mathrm{~h}$ at $25^{\circ} \mathrm{C}$, until the zoospores were released (Messenger et al. 2000). A drop of the zoospore suspension was mounted in Lactophenol blue solution (Merck, Darmstadt, Germany) and counted with the aid of a Neubauer chamber and a microscope at $20 \times$ magnification. Zoospore concentrations were adjusted with SDW. Unwounded plants were inoculated with $50 \mathrm{ml}$ of SDW containing $1 \times 10^{5}$ zoospores $\mathrm{ml}^{-1}$ and the controls treated with $50 \mathrm{ml} \mathrm{SDW}$. Soil was saturated for $48 \mathrm{~h}$ and plants were maintained in a greenhouse at $25 \pm 5^{\circ} \mathrm{C}$ until symptoms were obtained or for a maximum of 2 months. If plants remained symptomless for 2 months, the inoculation was repeated using fresh wounded plants that were inoculated with a 5-mm mycelial plug inserted into the stem. Control plants were also wounded, but only a sterile APDA plug was used. Root necrosis, percentage of fallen leaves, and presence of cankers were measured after 2 months. Root damage, measured as the presence of necrotic root lesions, was evaluated using a scale previously described (Vettraino et al. 2003), where: $0=$ no damage; $1=$ up to $25 \%$ damage;
$2=25$ to $50 \%$ damage; $3=50$ to $75 \%$ damage; $4=75$ to $100 \%$ damage. Pathogenicity tests were repeated.

Statistical analysis. To analyze differences in the percentage of fallen leaves obtained among treatments $(n=4$ for $P$. cinnamomi and Phy. vexans, $n=3$ for $P$. citrophthora and P. humicola, $n=2$ for Py. ultimum; 4 replicates for each treatment) an analysis of variance (ANOVA) was performed following a complete randomized design. Percent data were square root transformed before analysis. The means were separated using a Fisher's LSD test $(\alpha=0.05)$. The root

Table 3. Oomycete species isolated from decaying English walnut trees in the main walnut-production regions of Chile

\begin{tabular}{lrcccccc}
\hline & \multicolumn{6}{c}{ Orchards positive to oomycete } \\
\cline { 2 - 8 } Oomycetes & Coq & Val & Met & OHi & Mau & Bio & Total \\
\hline Phytophthora cinnamomi & 2 & 8 & 1 & 6 & 4 & 4 & 25 \\
Phytophthora citrophthora & 0 & 1 & 0 & 0 & 0 & 0 & 1 \\
Phytophthora humicola & 1 & 0 & 0 & 0 & 1 & 0 & 2 \\
Phytopythium vexans & 3 & 3 & 4 & 1 & 0 & 0 & 11 \\
Phytopythium litorale & 1 & 1 & 0 & 0 & 0 & 1 & 3 \\
Phytopythium mercuriale & 0 & 0 & 0 & 0 & 1 & 0 & 1 \\
Pythium ultimum & 1 & 2 & 0 & 0 & 0 & 0 & 3 \\
Pythium sp. & 3 & 1 & 2 & 2 & 2 & 0 & 10 \\
Total orchard sampled, no. & 10 & 13 & 9 & 9 & 10 & 4 & 55 \\
\hline
\end{tabular}

${ }^{\mathrm{a}}$ The administrative regions of Chile were: Coq: Coquimbo region, Val: Valparaíso region, Met: Metropolitana region, OHi: O'Higgins region, Mau: Maule region, Bio: Bío Bío region.

Table 1. Oomycete species isolated from English walnuts in Chile identified morphologically and molecularly in this study

\begin{tabular}{|c|c|c|c|c|}
\hline Collection number & Location $^{\mathbf{a}}$ & Identity (\%) ITS-Btub & Accession number ITS/Btub & GenBank ID ITS/Btub \\
\hline \multicolumn{5}{|c|}{ Phytophthora cinnamomi } \\
\hline PN 1859 & Coquimbo & $99-99$ & KU723593.1/KU899233.1 & MH424500/MH427876 \\
\hline PN 1858 & Valparaíso & $99-99$ & KU723593.1/KU899233.1 & KU961897/MH427875 \\
\hline PN 1886 & Metropolitan & $99-99$ & HQ643400.2/AB856781.1 & KU961899/MH427900 \\
\hline PN 1959 & O’Higgins & $99-99$ & KU723593.1/KU899233.1 & MH424502/MH427886 \\
\hline PN 1874 & Maule & $99-99$ & GU799635.1/KU899233.1 & KU961907/MH427879 \\
\hline PN 1980 & Bío Bío & $100-99$ & KU723593.1/HM041802.1 & MH236248/MH427889 \\
\hline \multicolumn{5}{|c|}{ Phytophthora citrophthora } \\
\hline PN 1994 & Valparaíso & $100-98$ & KT148901.1/JN605845.1 & MH368449/MH427892 \\
\hline \multicolumn{5}{|c|}{ Phytophthora humicola } \\
\hline PN 1875 & Maule & $99-99$ & JQ757060.1/JN935975.1 & KU961908/MH427893 \\
\hline PN 1943 & Coquimbo & $98-\mathrm{Ii}^{\mathrm{b}}$ & 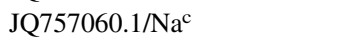 & $\mathrm{MH} 368445 / \mathrm{Na}^{\mathrm{c}}$ \\
\hline \multicolumn{5}{|l|}{ Phytopythium litorale } \\
\hline PN 1868 & Coquimbo & $99-\mathrm{Ii}^{\mathrm{b}}$ & $\mathrm{KT} 148891.1 / \mathrm{Na}^{\mathrm{c}}$ & KU961901/Na ${ }^{\mathrm{c}}$ \\
\hline PN 1857 & Valparaíso & $98-\mathrm{Ii}^{\mathrm{b}}$ & HQ643386.2/Na ${ }^{\mathrm{c}}$ & KU961896/ $\mathrm{Na}^{\mathrm{c}}$ \\
\hline PN 1982 & Bío Bío & $100-\mathrm{Ii}^{\mathrm{b}}$ & $\mathrm{KT} 148891.1 / \mathrm{Na}^{\mathrm{c}}$ & MH368448/Na ${ }^{\mathrm{c}}$ \\
\hline \multicolumn{5}{|c|}{ Phytopythium mercuriale } \\
\hline PN 1957 & Maule & $99-\mathrm{Ii}^{\mathrm{b}}$ & $\mathrm{KU} 211357.1 / \mathrm{Na}^{\mathrm{c}}$ & MH368446/Na ${ }^{\mathrm{c}}$ \\
\hline \multicolumn{5}{|l|}{ Phytopythium vexans } \\
\hline PN 1866 & Coquimbo & $99-99$ & HQ643400.2/AB856781.1 & KU961899/MH427900 \\
\hline
\end{tabular}

a Administrative regions of Chile.

${ }^{b}$ Ii: Insufficient information to analyze.

${ }^{\mathrm{c}}$ Na: Not analyzed.

Table 2. Survey of root and crown rot disease in English walnut orchards in central Chile

\begin{tabular}{lccr}
\hline Region $^{\mathbf{a}}$ & Affected orchards (\%) & Mean incidence $\mathbf{~}^{\mathbf{b}} \mathbf{( \% )}$ & Mean severity $^{\mathbf{c}}(\boldsymbol{\%})$ \\
\hline Coquimbo & 88.9 & 12.44 & 6.75 \\
Valparaíso & 100.0 & 28.56 & 18.08 \\
Metropolitana & 88.9 & 8.44 & 5.25 \\
O'Higgins & 88.9 & 18.33 & 13.81 \\
Maule & 100.0 & 7.89 & 6.75 \\
Total mean & 93.3 & 15.5 & 10.3 \\
\hline
\end{tabular}

a Administrative regions of Chile.

$\mathrm{b}$ The incidence was determined in 100 trees per orchard.

${ }^{c}$ The severity was estimated according to a canopy damage index $\left.{ }_{C} \mathrm{DI}(\%): \sum(\mathrm{nv})(\mathrm{NV})^{-1} 100\right)$. 
damage was statistically analyzed with the Wilcoxon test for nonparametric comparison $(\alpha=0.05)$. Data were analyzed using JMP v.13.0 software (SAS Institute Inc., Carolina del Norte, USA).

\section{Results}

Disease incidence and severity. Chlorosis, small leaves, defoliation, and shoot dieback were observed in $42(93.3 \%)$ of the 45 surveyed orchards, in all the walnut growing regions (Table 2). Brown to black cankers on the root and collar area of the trunk was found in $17(37.8 \%)$ of the 45 surveyed orchards. Dead trees were occasionally observed. The mean incidence and mean severity varied from 7.9 to $28.6 \%$ and from 5.3 to $18.1 \%$, respectively.

Isolation and identification. A total of seven oomycete species were identified from rotten roots and soil samples. Oomycete isolations from trunk pieces collected from cankered tissues were unsuccessful. Based on morphological and molecular identification, the oomycete species identified were $P$. cinnamomi, P. citrophthora, P. humicola, Phy. vexans, Phy. litorale, Phy. mercuriale, Py. ultimum, and Pythium sp. (Table 3). All the isolates had hyaline, cenocytic hyphae on APDA media. Sporangia were produced by all isolates (Erwin and Ribeiro 1996) (Table 4; Supplementary Fig. S1).

P. cinnamomi colonies were stellate or rosaceous; they produced hyphal swellings and chlamydospores. Sporangia were nonpapillated, ellipsoid to ovoid, and internal proliferations were obtained. The two isolates of $P$. humicola had dense, cottony colonies. Hyphal swellings and chlamydospores were not observed. Sporangia were papillated with internal proliferations. Isolates of $P$. citrophthora had a stellate colony on APDA, hyphal swellings were not produced, and chlamydospores were obtained. Sporangia were variable in shape with one or two papillae. Internal proliferations were absent. Isolates of Phy. vexans produced rosaceous colonies on APDA. Hyphal swellings and chlamydospores were not observed. Sporangia were subglobose, broad ovoid or obpyriform, nonpapillated, and/or proliferations were not observed. Isolates of Phy. litorale produced a dense, cottony colony on APDA. Hyphal swellings or chlamydospores were absent. Sporangia were subglobose to ovoid, usually with one papilla and internal proliferations. Isolates of Phy. mercuriale had cottony colonies on APDA. Hyphal swellings or chlamydospores were not observed. Sporangia were papillated subglobose to obovoid. Isolates of Py. ultimum had stellate colonies on APDA. No hyphal swellings or chlamydospores were observed. Sporangia were spherical, nonpapillated, and proliferations were not produced (Table 4).

The most frequently isolated Phytophthora species was $P$. cinnamomi, recovered from $45.5 \%$ of the orchards, followed by P. humicola in $3.6 \%$ and P. citrophthora in $1.8 \%$ of the orchards. Among Phytopythium, Phy. vexans was recovered from $20 \%$ of the orchards, followed by Phy. litorale in 5.5\% of the orchards and Phy. mercuriale in $1,8 \%$ of the orchards. Phytophthora cinnamomi was recovered from all production regions and Phy. vexans was recovered in samples from the Coquimbo, Valparaíso, Metropolitana, and O'Higgins regions (Table 3).

Molecular results. The molecular analysis corroborated the morphological approach. The species isolated from English walnut orchards were identified by ITS and beta tubulin genes as: $P$. cinnamomi, $P$. citrophthora, $P$. humicola, Phy. litorale, Phy. mercuriale, and Phy. vexans (Table 1; Supplementary Table S1 and S2). All isolates were identified, with an identity percentage between 98 and $100 \%$ for both gene regions.

Pathogenicity tests. Isolates of $P$. cinnamomi and $P$. citrophthora were pathogenic, causing crown and root rot in $J$. regia plants (Table 5). However, $P$. humicola isolates were nonpathogenic in

Table 5. Pathogenicity of isolates of Phytophthora (P.), Phytopythium (Phy.), and Pythium (Py.) species determined in 1-year-old English walnuts

\begin{tabular}{|c|c|c|c|}
\hline Isolates & $\begin{array}{l}\text { Defoliation } \\
(\%)\end{array}$ & $\begin{array}{l}\text { Cankered } \\
\text { plants, no. }\end{array}$ & $\begin{array}{c}\text { Mean of root } \\
\text { damage index }\left({ }_{R} D I\right)\end{array}$ \\
\hline \multicolumn{4}{|l|}{ P. cinnamomi } \\
\hline $\begin{array}{l}\text { Noninoculated } \\
\text { control }\end{array}$ & 0 & $0 / 4$ & 0 \\
\hline PN 1858 & $81^{\mathrm{b}}$ & $4 / 4$ & $4^{c}$ \\
\hline PN 1955 & $61^{\mathrm{b}}$ & $4 / 4$ & $4^{c}$ \\
\hline PN 1956 & $31^{\mathrm{b}}$ & $4 / 4$ & $4^{c}$ \\
\hline \multicolumn{4}{|l|}{ P. citrophthora } \\
\hline $\begin{array}{l}\text { Noninoculated } \\
\text { control }\end{array}$ & 0 & $0 / 4$ & 0 \\
\hline PN 1994 & $27^{\mathrm{b}}$ & $3 / 4$ & $4^{c}$ \\
\hline PN 1995 & $27^{\mathrm{b}}$ & $3 / 4$ & $3,5^{\mathrm{c}}$ \\
\hline \multicolumn{4}{|l|}{ P. humicola } \\
\hline $\begin{array}{l}\text { Noninoculated } \\
\text { control }\end{array}$ & 0 & $0 / 4$ & 0 \\
\hline PN 1875 & 0 & $0 / 4$ & 0 \\
\hline PN 1943 & 0 & $0 / 4$ & 0 \\
\hline \multicolumn{4}{|l|}{ Phy. vexans } \\
\hline $\begin{array}{l}\text { Noninoculated } \\
\text { control }\end{array}$ & 0 & $0 / 4$ & 0 \\
\hline PN 1866 & 0 & $0 / 4$ & 0 \\
\hline PN 1872 & 0 & $0 / 4$ & 0 \\
\hline PN 1909 & 0 & $0 / 4$ & 0 \\
\hline \multicolumn{4}{|l|}{ Py. ultimum } \\
\hline $\begin{array}{l}\text { Noninoculated } \\
\text { control }\end{array}$ & 0 & $0 / 4$ & 0 \\
\hline PN 1665 & 0 & $0 / 4$ & $1^{\mathrm{c}}$ \\
\hline
\end{tabular}

a Numerator means number of plants with canker, denominator means total of plants evaluated.

${ }^{b}$ Number of fallen leaves: values are significantly different from the control $(\alpha=0.05)$ using Fisher's least significant difference (LSD) test.

${ }^{c}$ Mean of root damage index: values are significantly different from the control $(\alpha=0.05)$ using non parametric Wilcoxon test.

Table 4. Morphological characteristics of sporangium of oomycete species isolated in the current study

\begin{tabular}{|c|c|c|c|c|c|c|}
\hline & Shape & Papillae & Proliferation & $\begin{array}{l}\text { Mean length } \\
(\mu \mathrm{m})\end{array}$ & $\begin{array}{l}\text { Mean width } \\
(\mu \mathrm{m})\end{array}$ & $\begin{array}{l}\text { Mean length/width } \\
\text { ratio }\end{array}$ \\
\hline \multicolumn{7}{|l|}{ Phytophthora } \\
\hline P. cinnamomi & Ellipsoid to ovoid & Non & Internal & $56.0 \pm 12.3^{\mathrm{a}}$ & $34.8 \pm 8.1^{\mathrm{a}}$ & $1.6 \pm 0.2^{\mathrm{a}}$ \\
\hline P. citrophthora & $\begin{array}{l}\text { Spherical, ovoid, obpyriform to } \\
\text { ellipsoid }\end{array}$ & Present, 1 or 2 & $\mathrm{ND}^{\mathrm{b}}$ & $43.8 \pm 4.3$ & $29.0 \pm 3.1$ & $1.5 \pm 0.1$ \\
\hline P. humicola & Ovoid to obpyriform & Non & Internal & $60.5 \pm 8.8$ & $47.8 \pm 9.4$ & $1.3 \pm 0.1$ \\
\hline \multicolumn{7}{|l|}{ Phytopythium } \\
\hline Phy. vexans & Subglobose, broad ovoid or obpyriform & Non & ND & $24.8 \pm 3.7$ & $19.9 \pm 2.6$ & $1.3 \pm 0.2$ \\
\hline Phy. litorale & Subglobose or ovoid & Usually present & Internal & $30.4 \pm 1.6$ & $25 \pm 1.2$ & $1.2 \pm 0.0$ \\
\hline Phy. mercuriale & Subglobose to ovoid & Present & ND & $53.2 \pm 8.6$ & $22.8 \pm 1.2$ & $2.3 \pm 0.3$ \\
\hline \multicolumn{7}{|c|}{ Pythium } \\
\hline Py. ultimum & Spherical & Non & ND & $22.6 \pm 3.0$ & $19.4 \pm 2.0$ & $1.2 \pm 0.1$ \\
\hline
\end{tabular}

${ }^{\mathrm{a}} \pm$ SD: Standard deviation.

${ }^{\mathrm{b}}$ ND: Not detected. 
wounded and unwounded plants. Py. ultimum only caused leaf chlorosis and slight root rot (Table 5).

Defoliation, crown rot, and root damage were observed in plants inoculated with P. cinnamomi 7 days after inoculation (Table 5, Fig. 2e). Root damage was observed as a cortical black necrosis, but the xylem was not affected (unpublished results). Crown rot was characterized by a cortical necrosis from 0.3 to $4.8 \mathrm{~cm}$ long, extending from the cortex to the cambial tissue and, in most plants, exudation of black droplets was also observed (Fig. 2d). On the other hand, $P$. citrophthora caused cortical necrosis from 0.5 to $7.6 \mathrm{~cm}$ long 14 days after inoculation (Table 5). Crown rot always progresses from the cambial zone to the surface of the shoots. Plants inoculated with Py. ultimum did not lose leaves or develop crown rot; however, one isolate produces a slight root necrosis 45 days after inoculation. Pathogens from all trials were reisolated from root injuries and were morphologically identified. No pathogens were isolated from asymptomatic control plants. Plants inoculated with $P$. humicola and Phy. vexans showed no symptoms 2 months after zoospore inoculation, and no symptoms were observed 2 months after wounding the main stem and placing mycelium of $P$. humicola and Phy. vexans. 7

\section{Discussion}

This study provided the first quantitative report of the incidence and severity of Phytophthora root and crown rot disease of English walnut in Chile, demonstrating the presence of $P$. cinnamomi, $P$. citrophthora, P. humicola, Phy. vexans, Phy. litorale, Phy. mercuriale, Py. ultimum, and Pythium sp. Nevertheless, only P. cinnamomi and $P$. citrophthora were pathogenic to English walnut. Py. ultimum caused limited levels of root damage to English walnut seedlings, but defoliation or crown rot cankers were not obtained. Py. ultimum has been described as a ubiquitous soil inhabitant that can attack many horticultural crops (Hendrix and Campbell 1973). To our knowledge, this is the first study that has completed Koch's postulates for Py. ultimum in J. regia worldwide. However, further studies are needed before concluding that Py. ultimum is the cause of root and crown rot of English walnut. Phy. vexans has been described as a pathogen in several species such as Fraser fir and apple seedlings (Ivors et al. 2008; Tewoldemedhin et al. 2011), and it was widely distributed in Chilean English walnut orchards; nevertheless, this species was not pathogenic to J. regia plants.

This study also demonstrated the importance of Phytophthora root and crown rot affecting English walnut at a national level. In previous studies (English et al. 1967; INIA 1969; Rojic and Cancino 1975), the disease was reported only in the Valparaíso region of Chile; however, the present survey documented the presence of a high incidence of Phytophthora root and crown rot in all English walnut along a 700-km north-south axis, across a range of diverse climatic zones and diverse soil conditions, with mean annual rainfall of 370 to $1,055 \mathrm{~mm}$. However, in the present study, the highest incidence of the disease was observed in the Valparaíso and O'Higgins regions, where the oldest English walnut orchards were planted, and where several avocado orchards were converted to walnut, even after avocado root rot disease had been previously detected (S. Saa, unpublished).

Isolation of oomycete species was not successful in all orchards where symptoms were observed. This could be due to the fact that in several orchards the trees were already dead and saprophytic species had colonized the tissues before sampling, or to the possible presence of inhibitory substances secreted by the walnuts in response to injuries made while selecting the tissue samples for isolations, or perhaps isolations were performed when Phytophthora was less active in the orchards. For example, in Rojic and Cancino (1975), the isolation of Phytophthora from English walnut trees was successful between April and May, which corresponds to autumn in Chile. Mircetich and Matheron (1983) agree that the success of isolation from California walnut orchards was greater from late autumn to early spring, and was sporadic and difficult from late spring and summer. In our case, isolations were more successful in early spring and autumn than in summer months.
Morphological and molecular features allowed the identification of $P$. cinnamomi and $P$. citrophthora attacking English walnuts trees in Chile, coinciding with previous reports in Chile and in the world (Rojic and Cancino 1975; Stamps et al. 1990). In previous studies, $P$. cactorum was also identified affecting English walnut trees in the Valparaíso region (English et al. 1967; INIA 1969). However, in this study $P$. cactorum was not isolated. This species has also been reported to cause crown rot of walnut trees in California (Mircetich and Matheron 1983), so it is plausible that this species could be found in other Chilean English walnut orchards not surveyed in the present study.

Our pathogenicity tests revealed that $P$. cinnamomi and $P$. citrophthora were the most aggressive species affecting $J$. regia plants. The result of the $P$. cinnamomi pathogenicity test is in accordance with previous studies carried out in Europe (Belisario et al. 2006, 2009) and the United States (Mircetich and Matheron 1983). P. citrophthora has also been described affecting English walnuts in the United States and Greece (Holevas et al. 2000; Mircetich and Matheron 1983).

Because our research indicates that $P$. cinnamomi is the most widely distributed species affecting English walnut in Chile, integrated management approaches for the disease should emphasize this species. It may be advisable to avoid planting English walnuts in soils previously devoted to avocado or blueberry production that sustained losses due to the pathogen. However, because the RX1 rootstock (Juglans microcarpa $\times$ J. regia) was recently reported to provide superior resistance to $P$. cinnamomi in California (Browne et al. 2015), this rootstock and others with similar traits would be promising candidates for testing in Chilean orchards infested with the pathogen. Fosetyl-al has been effective for P. cinnamomi control (Belisario

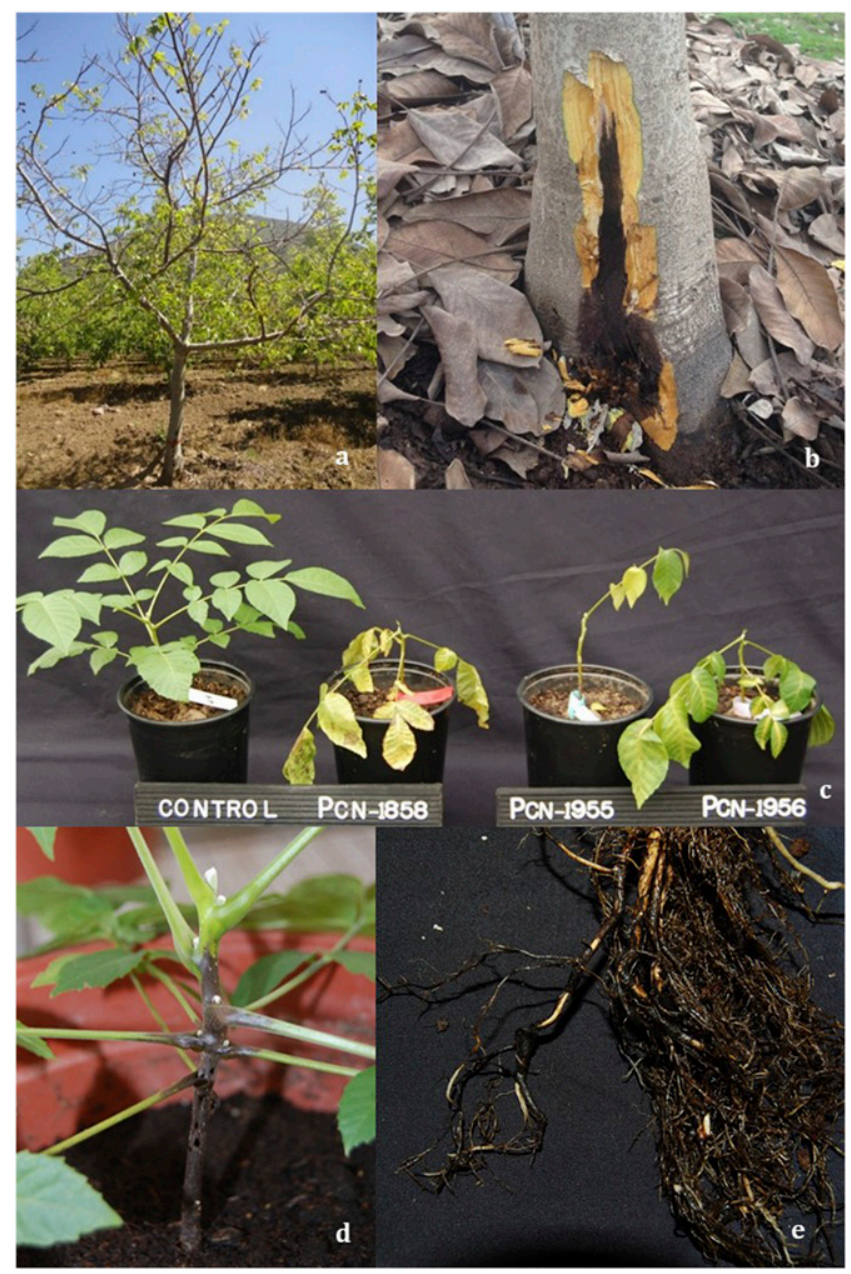

Fig. 2. Phytophthora cinnamomi root rot in English walnut (Juglans regia). (a) English walnut tree with chlorosis and leaf fall. (b) Crown rot in an English walnut tree. (c) Pathogenicity test on J. regia with three isolates of $P$. cinnamomi. (d) Cortical necrosis and exudation of black droplets. (e) Rooted roots. 
et al. 2009). Phosphonate treatments provided some suppression of $P$. citricola on walnut (Browne et al. 2011); however, future research in Chile may be needed to determine its effectiveness against $P$. cinnamomi in English walnut.

Finally, in addition to a focus on management of $P$. cinnamomi, it will also be important to monitor and manage, over time, additional oomycete pathogens of English walnut in Chile. For example, we found that $P$. citrophthora was pathogenic in $J$. regia plants, and therefore rootstock resistance, as well as chemical and cultural control strategies for this species, should also be evaluated under Chilean conditions.

\section{Acknowledgments}

We thank Patricio Nuñez, Marjorie Pérez, and Iván Cortés for their technical assistance in the laboratory and greenhouse studies, ant Mary Hopkins for the technical English revision of this manuscript.

\section{Literature Cited}

Belisario, A., Cacciola, S. O., and Magnano di San Lio, G. 1997. Phytophthora cactorum on walnut seedlings in Italian nurseries. Eur. J. For. Pathol. 27: 137-146.

Belisario, A., Galli, M., and Wajnberg, E. 2009. Evaluation of Juglans species for resistance to Phytophthora cinnamomi: Differences in isolate virulence and response to fosetyl-Al. For. Pathol. 39:168-176.

Belisario, A., Luongo, L., Galli, M., and Vitale, S. 2012. First report of Phytophthora megasperma associated with decline and death of common walnut trees in Italy. Plant Dis. 96:1695.

Belisario, A., Luongo, L., Vitale, S., Galli, M., and Haegi, A. 2016. Phytophthora gonapodyides causes decline and death of English (Persian) Walnut (Juglans regia) in Italy. Plant Dis. 100:2537.

Belisario, A., Maccaroni, M., and Vettraino, A. M. 2001. Phytophthora cinnamomi agente del marciume basale del noce nell'Italia Settentrionale. Petria 11:149-157.

Belisario, A., Maccaroni, M., Vettraino, A. M., Valier, A., and Vannini, A. 2006. Phytophthora species associated with decline and death of English walnut in Italy and France. Acta Hortic. 401-407.

Belisario, A., Maccaroni, M., Vettraino, A. M., and Vannini, A. 2003. First report of Phytophthora nicotianae and P. citricola associated with English walnut decline in Europe. Plant Dis. 87:315.

Besoain, X., Arenas, C., Salgado, E., and Latorre, B. A. 2005. Efecto del periodo de inundación en el desarrollo de la tristeza del palto (Persea americana), causada por Phytophthora cinnamomi. Cien. Inv. Agrar. 32:97-103.

Browne, G. T., Leslie, C. A., Grant, J. A., Bhat, R. G., Schmidt, L. S., Hackett, W. P., Kluepfel, D. A., Robinson, R., and McGranahan, G. H. 2015. Resistance to species of Phytophthora identified among clones of Juglans microcarpa $\times J$. regia. HortScience 50:1136-1142.

Browne, G. T., Prichard, T. L., Schmidt, L. S., and Krueger, W. H. 2011. Evaluation of phosphonate treatments for control of Phytophthora crown rot of walnut. Plant Health Prog. 12:11.

De Cock, A. W. A. M., Lodhi, A. M., Rintoul, T. L., Bala, K., Robideau, G. P., Abad, Z. G., Coffey, M. D., Shahzad, S., and Lévesque, C. A. 2015. Phytopythium: Molecular phylogeny and systematics. Persoonia 34:25-39.

Dervis, D. 2016. First report of Phytophthora chlamydospora causing root rot on walnut (Juglans regia) trees in Turkey. Plant Dis. 100:2336.

English, H., Moller, W. J., and Nome, S. F. 1967. New records of fungus disease of fruit crops in Chile. Plant Dis. Rep. 51:212-213.

Erwin, D. C., and Ribeiro, O. K. 1996. Phytophthora Diseases Worldwide. American Phytopathological Society, St. Paul, MN.

Fichtner, E. J., Browne, G. T., Mortaz, M., Ferguson, L., and Blomquist, L. 2016. First report of root rot caused by Phytopythium helicoides on pistachio rootstock in California. Plant Dis. 100:2337.

Glass, N. L., and Donaldson, G. C. 1995. Development of primer sets designed for use with the PCR to amplify conserved genes from filamentous ascomycetes. Appl. Environ. Microbiol. 61:1323-1330.

Guajardo, J., Saa, S., Camps, R., and Besoain, X. 2017. Outbreak of crown and root rot of walnut caused by Phytophthora cinnamomi in Chile. Plant Dis. 101:636.
Hendrix, F. F., and Campbell, W. A. 1973. Pythiums as plant pathogens. Annu. Rev. Phytopathol. 11:77-98.

Holevas, C. D., Chitzanidis, A., and Pappas, A. C. 2000. Disease agents of cultivated plants observed in Greece from 1981 to 1990. Benaki Phytopathol. 19:1-96.

INIA. 1969. Reconocimiento de las enfermedades del nogal en la provincia de Aconcagua. Instituto de Investigaciones Agropecuarias (INIA). Agric. Tec. Chil. 29:97-98.

Ivors, K. L., Abad Z. G., and Benson, D. M. 2008. Evaluating the pathogenicity of Pythium vexans isolates from Fraser Fir in North Carolina. Plant Health Progr. doi.org/10.1094/PHP-2008-1006-01-RS.

Jeffers, S. N., and Martin, S. B. 1986. Comparison of two media selective for Phytophthora and Pythium species. Plant Dis. 70:1038-1043.

Kovacs, J., Lakatos, F., and Szabó, I. 2013. Occurrence and diversity of soilborne Phytophthoras in a declining black walnut stand in Hungary. Acta Silv. Lignaria Hung. 9:57-69.

Kurbetli, I. 2013. Phytophthora cinnamomi associated with root and crown rot of walnut in Turkey. J. Phytopathol. 161:287-289.

Larach, A., Besoain, X., and Salgado, E. 2009. Crown and root rot of highbush blueberry caused by Phytophthora cinnamomi and $P$. citrophthora and cultivar susceptibility. Cien. Inv. Agrar. 36:433-442.

Latorre, B. A., Wilcox, W. F., and Bañados, M. P. 1997. Crown and root rots of table grapes caused by Phytophthora spp. in Chile. Vitis 36:195-197.

Matheron, M. E., and Mircetich, S. M. 1985. Relative resistance of different rootstocks of English walnut to six Phytophthora spp. that cause root and crown rot in orchard trees. Plant Dis. 69:1039-1041.

McKinney, H. H. 1923. Influence of soil temperature and moisture on infection of wheat seedlings by Helminthosporium sativum. J. Agric. Res. 26:195-225.

Messenger, B. J., Menge, J. A., and Pond, E. 2000. Effects of gypsum on zoospores and sporangia of Phytophthora cinnamomi in field soil. Plant Dis. 84:617-621.

Mircetich, S. M., Browne, G. T., Matheron, M. E., and Teviotdale, B. L. 1998. Armillaria and Phytophthora root and crown rot diseases. Ch. 28 in: Walnut Production Manual. University of California. Publ. 3373.

Mircetich, S. M., and Matheron, M. E. 1983. Phytophthora root and crown rot of walnut trees. Phytopathology 73:1481-1488.

ODEPA. 2016. Frutales: Superficie y producción. Oficina de Estudios y Políticas Agrarias (ODEPA). Retrieved 6 July 2017 from http://www.odepa.gob.cl/ frutales-superficie-y-produccion-2/

Rojic, J., and Cancino, L. 1975. Phytophthora cinnamomi Rands y P. citrophthora (Smith y Smith) Leonian agentes causales de la pudrición del cuello del nogal (Juglans regia) en Chile. Inv. Agric. 3:201-204.

Spies, C. F. J., Mazzola, M., and McLeod, A. 2011. Characterization and detection of Pythium and Phytophthora species associated with grapevines in South Africa. Eur. J. Plant Pathol. 131:103-119.

Stamps, D. J., Waterhouse, G. M., Newhook, F. J., and Hall, G. S. 1990. Revised tabular key to the species of Phytophthora. CAB International Mycological Institute, Kew, Surrey, England. Mycol. Pap. 162:1.

Tewoldemedhin, Y., Mazzola, M., Botha, W. J., Spies, C. F. J., and McLeod, A 2011. Characterization of fungi (Fusarium and Rhizoctonia) and oomycetes (Phytophthora and Pythium) associated with apple orchards in South Africa. Eur. J. Plant Pathol. 130:215-229.

Themann, V. K., and Werres, S. 1998. Verwendung von Rhododendronblättern zum Nachweis von Phytophthora-Arten in Wurzel- und Bodenproben. Nachrichtenblatt Dtsch. Pflanzenschutzdienstes. 50:37-45.

Utkhede, R. S., and Smith, E. M. 1991. Phytophthora and Pythium species associated with root rot of young apple trees and their control. Soil Biol. Biochem. 23:1059-1063.

Vettraino, A. M., Belisario, A., Macaroni, M., Anselmi, N., and Vannini, A. 2002 First report of Phytophthora cryptogea in walnut stands in Italy. Plant Dis. 86 328

Vettraino, A. M., Belisario, A., Maccaroni, M., and Vannini, A. 2003. Evaluation of root damage to English walnut caused by five Phytophthora species. Plant Pathol. 52:491-495.

Waterhouse, G. M. 1968. The genus Pythium Pringsheim. Commonwealth Mycological Institute, Kew, Surrey, England.

White, T. J., Bruns, T., Lee, S., and Taylor, J. 1990. Amplification and direct sequencing of fungal ribosomal RNA genes for phylogenetics. Pages 315-322 in: PCR Protocols: A Guide to Methods and Applications, Chapter 38. Academic Press Inc., New York. 